\title{
The Domestic Violence. Law no. 9669 of 18/12/2006 "Measures Against the Violence in Family Relations" in Albania
}

\author{
Arjan Qafa \\ Candidate to Doctor in Law \\ European University of Tirana, Albania \\ arjan.qafa@hotmail.com
}

\section{Doi:10.5901/mjss.2014.v5n3p36}

\section{Abstract}

The domestic violence is a bitter reality of all humanity e a phenomenon which has taken worrying dimensions for the society. The domestic violence is increased during last years not only as phenomenon with social, economic and psychological consequences that impacts significantly the human rights. The extended transition has created more social and economic issues on all democratic societies, but in our country it is not ended for a long time. The democratic system remains unfulfilled with the special legislation in this area, central and local institutions are weak, or are not at the right level to take appropriate measures to reduce the violence of domestic violence, but it is associated with the difficult and problematic transition that our country has had.

Keywords: domesticviolence, Albanian Family Code. Law no. 9669 of 18/12/2006 "On measures against the violence on family relations", prevention of domestic violence, efficient means for prevention of the domestic violence.

\section{Introduction}

\subsection{Measures against the violence in family relations in Albania}

On 2006, Albanian Parliament has approved the law no. 9669 dated 18/12/2006 "On measures towards the domestic violence", that aiming to prevent and reduce the domestic violence in all its forms, throughout appropriate legal measures, and ensuring protection throughout legal means to family's members as victims of domestic violence. The Law has the following principal objectives:

1. The constitution of a coordinated network of authorities responsible to provide protection, support and victims' rehabilitation, consequences' relief and prevention of domestic violence.

2. The guidance of efforts for constituting the frameworks and relevant authorities at central and local level regarding the supporting victims and preventing domestic violence.

3. Judicial system empowering to take precautions towards domestic violence, and

4. Ensuring/guarantying fast services, free for victims of domestic violence offered by courts and other agencies of rule implementing according to the law.The best globally experiences indicate that the community involvement in addressing domestic violence brings social pressure on abusers and it is more successful on reducing and ending of domestic violence than other methods, legal punishment included.

\subsection{Measures against the violence in family relations in Albania}

The domestic violence is a bitter reality of all humanity e a phenomenon which has taken worrying dimensions for the society. The domestic violence is increased during last years not only as phenomenon with social, economic and psychological consequences that impacts significantly the human rights. Every one of us has the right to live in a secure way, and as per own needs, not harmed by others. The domestic violence harms the security and family's calmly, impacts the children, women, old people and other family members. The extended transition has created more social and economic issues on all democratic societies, but in our country it is not ended for a long time. The democratic system remains unfulfilled with the special legislation in this area, central and local institutions are weak, or are not at the right level to take appropriate measures to reduce the violence of domestic violence, but it is associated with the difficult and problematic transition that our country has had. 
A very significant role in preventing domestic violence have played legislative initiatives since the process of democratization of the society has made necessary the role of the justice system in order to provide families with the support needed to prevent and protect its members from abuse and to maintain consistency and harmony in family life.

One of more significant goals of justice is to ensure respect and enjoyment of the rights of the individual part of which is also the protection from domestic violence as the most serious form of violence.

In the area of protecting and ensuring the respect of Human Rights and Fundamental Freedoms of the Individual, the legal framework and its effectiveness impacts the live all individuals of the society because as much as sophisticated be the legislation more ensured these rights are.

So, one of more efficient legal acts in ensuring the human rights and fundamental freedoms of the individual is the Constitution of the Republic of Albania, which is characterized by the non-discrimination and equality principle.

In this regard the cooperation of all national institutions between each other, whether central or local, with all nongovernmental organizations, and NGOs who operate in the territory of our country is needed, taking in consideration all experiences of Western countries.

So, the researchers of this phenomenon pay special attention to and take all measures to advise the competent authorities to approve relevant legal drafts to protect the family.

When we are discussing to domestic violence we have to understand the violence exerted towards the members of the same family, towards women, men, children, parents, but not avoid even the violence suffered by a family from another family, being neighbour, other people with parental links who have different proprietor interests and so on.

"The domestic violence means all forms of physical, psychological, sexual and economical abuse carrying out among members of the same family and intimate partners and, as such, is damages physical and spiritual welfare of individuals involved." The domestic violence is not only an illegal act violating the fundamental rights of family's members from other members of the same family, but also a social problem that has historically coexisted with the families.

\section{The Domestic Violence is Shaped on Different Forms}

- Physical violence,

- Psychological violence

The domestic violence is expressed in different forms, but in general it can be summarized by the need to have control or authority over the violated people. Although a number of factors exists that lead to domestic violence, this always is associated with inequalities and disequilibrium of power in relationships within the family. All continuing efforts of international organizations in the area of the family's rights and the rights of victims, it has been a permanent improvement, because all countries participating in these conventions undertake rights and obligations regarding the family rights.All countries, signatories of these treaties are obligated to take in consideration even the recommendations of these conventions, because the role of public authorities is very important, not only in protecting the human rights and applying the rules, but also preventing further use of the violence.

\section{The Responsibility of the Country Member of the Conventions and Concrete Recommendations}

- According to the international law, the counties are liable to prevent, investigate and punish the violence towards the women, who is taken as reference of all family, as well as to ensure that the victims profit appropriate means and indemnities, despite the fact is it is carried out by state agents or by private individuals (General Recommendation no. 19, article 8; DVAW, article 4).

- On general recommendation, the CEDAW Committee recognises the violence towards the women considering the domestic violence as a form of the discrimination.

- "....any distinction, exclusion or restriction made based on the sex that has the effect or purposethe damage or annulment of the recognition, enjoyment or exercise by women ... of human rights and fundamental freedoms in the political, economic, social, cultural, civil or any other field".

- The Council of Ministers has also noted that the inequities relations of the power between men and women and the patriarchal framework of the family are factors contributing to the domestic violence.

As above, taking in consideration these recommendations and the obligations our country as member of ratified treaties has, and with initiative of NGO-s, Albanian Government has drafted the law regarding the measures towards domestic violation. So, we know that the protection of dignity, the respect of human rights and fundamental freedoms is a constitutional obligation. Based on the Constitution, the life, marriage, family, and family's members enjoy special 
protection from the State. Regarding the family's protection, the Constitution doesn't avoid the family's protection even in cases when the latter is nor created with the consequences of domestic violence and the escalation of the violence up to get life of closer relatives, or up to the restriction to make suicide become enough serious problem not only for the society but specially for the authorities of the law implementation. The new Law is appropriated to the modern standards of the European countries and treaties ratified by our country.

On 2006, Albanian Parliament has approved the law no. 9669 dated 18/12/2006 "On measures towards the domestic violence", that aiming to prevent and reduce the domestic violence in all its forms, throughout appropriate legal measures, and ensuring protection throughout legal means to family's members as victims of domestic violence.

\section{The Law has the following principal objectives:}

5. The constitution of a coordinated network of authorities responsible to provide protection, support and victims' rehabilitation, consequences' relief and prevention of domestic violence.

6. The guidance of efforts for constituting the frameworks and relevant authorities at central and local level regarding the supporting victims and preventing domestic violence.

7. Judicial system empowering to take precautions towards domestic violence, and

8. Ensuring/guarantying fast services, free for victims of domestic violence offered by courts and other agencies of rule implementing according to the law.

This rule defines as violence "each activity or inactivity of a person towards another bringing as consequence the infringement of physical, moral, psychological, sexual, social and economic integrity".

In following, as domestic violation is defined "any violating act exercised towards persons who are, or have been into family relationship". According to the law, as family's members are included:

a. the spouse or common-law partner, or ex-spouse, or ex-common-law partner;

b. brothers, sisters, the heritage in strait way

1. Law no. 9669 dated December 18th, 2006 includes adopting parents, and adapted children;

c. The spouse or common-law partner of persons specified on letter " $b$ ";

d. the heritage in strait way, including also parents, and adopted children of the spouse or common-law partner;

e. the brothers and sisters of the spouse if they have lived together at least three last months;

f. children of spouse or common-law partner.

In this law, the protective measures towards domestic violence, including protecting order issued by the court (a sentence issued by the court that foreseen protective measures to the victim), and immediate protective orders (a temporary order issued by the court that is valid until the same issue a protective order) are foreseen.When the request for issuing a protective order is submitted by the police or the prosecutor office, even if the victim (under pressure) wants to withdraw the suit or to cancel the case, such thing doesn't have impact on process's ongoing. So because of the violated woman is the principal witness, the law defines her as "witness obligated to testify".Failure to execute a protective order or an immediate protective order constitutes a criminal offence, as per article 320 of Criminal Code; consequently, its authormaybe arrestedwithoutwarrant.Following the recommendations, certain amendments on Law no. 23/2012 "On some supplements and variations on the law no. 7895 dated 27/01/1995, "Criminal Code of the Republic of Albania" as amended, are happened.

- Our Criminal Code pays special attention to the protection of individual, freedoms and human rights.

- Most of its disposals (Criminal Code) ensure protection by actions that violate the physical, mental and sexual integrity of an individual, and directly or not ensure to women special protection by domestic violence and general violence, as well.

- The domestic violence, special criminal offence - fulfilment of the recommendations of CEDA Committee, and international standards.

- Severing of the punishment's measure

The judicial system which is operating in the Republic of Albania constitutes a highly efficient means to protecting and ensuring the rights and fundamental freedoms of the individual, and so preventing the violence and offering protection to victims. As reference in this regards a part of judicial practice of certain courts for the period 01/01/2011 to 30/06/2012 are taken in consideration.On judicial practice of some courts are noted these concerns, part of victims, who were presented to the Police Station and Prosecution Office of relevant districts, and the latter have submitted to the court their request for the issuing of protection order in court.According to the Law no. 9669 dated 18/12/2006 "On measures towards domestic violence", the victims have the faculty to be presented in trial with their notification, but even 
in case when those don't be presented, the procedure related to the examination of protection's order continues in court. Regarding to the practice, in judges of some courts have complied with the dispositions of the Civil Procedure Code related to the notification of the parties treating it as a civil case. In certain cases the victims were resigned, not appearing to the court without giving reasons, despite notice received by the court. Certain courts have suspended these cases not taking in consideration the specific law because the cases presented by the Prosecution Office and/or Police Station have to be proceeded primarily.

In some courts, the Law no. 9669 dated 18/12/2006 "On measures towards domestic violence" is wrongly understood because in the cases presented by the Police Station and Prosecution Office have to be proceeded mainly, despite notification of violated individuals, the not-appearance doesn't constitute a barrier for the examination of the case presented to be examined by the court, so the case continues in a procedure of the case proceeding primarily. Some courts have decided the case's suspension reasoning that the victim was informed and he/she didn't be appeared in court, basing their decision in the disposals of Civil Procedure Code, avoiding the disposals of specific law on domestic violence. This approach of legal procedure is noted by relevant instances maintaining legal position for the unification of the practice now and on.We are referred to the "violence" on preparation of this research on domestic violence as a model of abusive behaviour in any relationship that is exercised by an intimate partner or by other family's members to take and conserve the authority and control over other intimate partner or family's members. The domestic violence includes acts or threatening for physical, sexual, emotional and psychological acts impacting other individuals. The issue remaining opened to the debate is, so, that of identification of factors having contributed in that field and differences among them.Each of us has the right to live his/her life in a safe manner according to his/her own needs, without being disturbed by whatever individual, closer or far in genre, spouse, or common-law partner, neighbour, or having proprietor or not-proprietor interests.As mentioned above the domestic violence harms the security and its calm, impacts children, women, old people and other family's members etc.

\section{The Factors Impacting Domestic Violence are:}

Educational level, employment, economic factors, inequality on power to realize their private interests. The educational level impacts the diminishing of domestic violence elements, but where an educational difference in level exists between spouses, necessarily would be existed violence's elements because of this educational inequality. The employment is also e significant factor of domestic violence when two spouses are unemployed and have no enough incomes to face the living costs. But, even in cases when one of the spouses is employed, the domestic violence is presented due to inequity between them resulting on the creation of conflict elements. At the same time, the economic dependence of the women by men is presented not only as a consequence but also as a factor of greater risk for domestic violence.

\section{The Theories to Domestic Violence}

During last 50 years Western researchers have presented a variety of theories to explain the domestic violence. For those who treat their work on domestic violence and develop effective preventive measures and policies, and legal protection, it is important to understand the different theoretical perspectives, and that not all theories are supported by researchers. The researchers otherwise admit that in fact it is problematic to be referred to the behaviour of abused people due to a mental or personality disorder, because the personality of a abused people can be the victimization's result. (11)The researches have shown that the most party of the domestic violence cannot be explained with these theories based on individual level. There are a few supports towards the opinion that the personality's disorder or mental disease is responsible for causing the domestic violence (12).In framework level of analysis, there are used two different theories - the theory of domestic violence and the feminist theory - to explain the domestic violence. These theories admit that the domestic violence is a behaviour learned throughout the observation and empowering into family as well as in the society. The domestic violence is repeated because it functions - the domestic violence allows that the abuser have control on the victim throughout the fear and threatening.In addition, the abuser is able to empower his/her abusive behaviour due to sanctioned beliefs at social level imposing that the men have the right to control women in family and in intimate relations, as well as to use the violence for "right causes" to control and discipline the spouse/common-law partner and/or children. The theory of domestic violence considers the physical attacks made by a family's member towards another family's member as a tactical response versus conflicts being undivided into family live $(13,14)$. While the power can be exercised equally by the husband and wife, the abuse with the wife happens frequently in families in which the husband has more power than the wife and/or the wife is considered as property or is under control of her 
husband (15).In addition, some times the violence towards the children is exercised by parents, sisters and bigger brothers, and other bigger relatives having power and control on smaller children.

According to the theory of domestic violence, the family is considered as an arena where the violent behaviour is learned and transmitted through generations, cases in which there are evidenced cycles of violence within the family. The researchers debate on the degree of empirical support that is an evidence of the theory of domestic violence. While a number of studies have noted that the abusers were themselves abused where they were children or have been present when their mothers were abused by their fathers, other studies didn't found a significant relation between childhood experiences with domestic violence, and exercising of domestic violence as adults. The lack of consistence in different researches may happen due to not-considering by the theory of domestic violence of the disequilibrium of the power between husband and wife and parents and children. Last, the feminist theories consider the male domination as a key element in domestic violence against the women. The dependence of women towards male authority is believed to be institutionalized in the framework of patriarchal societies that consists on a social framework giving women an inferior status, and a culture serving the reinforcement of this rule's acceptance. This evaluation is supported by researchers who examined cultures and societies which have shown mutual relations between social patriarchal frameworks and figures of violence against the women.In a particular way, the spouses patriarchal beliefs were found to be associated with women' beating.Cross-cultural studies suggest that the wives' abuse is a common practice in patriarchal societies where the cultural values, including norms and social and religious believes dictate the male domination on gender relations, excuse the violence against the women and constitute differencebehaviour codes for men and women.

In comparison, the economic power and the authority of the women into family are mutually related to the lower level of the violence against the spouses. The feminist theories consider also the stereotypes about the roles and responsibilities "appropriate" for men and women into family that empower the belief that men are dominant and the women are subordinated to the men.It is expected that the women show the obedience and respect towards their husbands, and the males have the right to govern and control their wives throughout any necessary means to conserve their dominating status into family. The researches have noted, indeed, that the point-of-view about women as depended towards men is a fundamental cause of the domestic violence against the women.In reality, many men and women consider the violence as a normal part of an intimate and marital relationship.Following the feminist theory, the domestic violence is a manifestation of gender inequality existing in Albania. At the same time, the domestic violence still serves to perpetuate the women inequality. The gender inequality is reflected also on the response of women towards the domestic violence, especially their fear to speak or to seek assistance for domestic violence.Albania offers a significant role on domestic violence's preventing throughout the accession in convention and treaties. The higher guarantee on protecting freedoms and human rights are offered by the European Convention on Human Rights as a special instrument in this matter, the Social Charter, The Universal Declaration of Human Rights, the European Convention against the torture, treatment and inhuman and degrading punishment; the Convention "On elimination of all forms of discrimination against the women". After 1990, the approach of Albanian legislation with standards of international legislation in order to protecting and ensuring the human rights and fundamental freedoms became eminent. This is followed with signing and ratifying of some treaties and agreements in the field of protecting and ensuring the human rights. The Republic of Albania is member on treaties drafted by the United Nations and Council of Europe, as well as of the European Convention against the torture, treatment and inhuman and degrading punishment. The best globally experiences indicate that the community involvement in addressing domestic violence brings social pressure on abusers and it is more successful on reducing and ending of domestic violence than other methods, legal punishment included.

\section{References}

WHO, 2005, pp. 90-91.

Pinheiro (2006). World Report on Violence against Children. Geneva, Switzerland: United Nations Publishing Services.

Bui \& Morash (1999). Domestic Violence in the Vietnamese Immigrant Community: An Exploratory Study. Violence Against Women, Vol. 5, No. 7, pp. 769-795.

Gleason (1993). Mental Disorders in Battered Women: An Empirical Study. Violence and Victims, Vol. 8, pp. 353-368.

Snell, Rosenwald \& Robey (1964). The Wife Beater's Wife: A Study of Family Interaction. Archives of General Psychiatry, Vol. 11, pp. 107-112.

Walker (1979). Battered Women. New York: Harper and Row.

Weitzman \& Dreen (1982). Wife Beating: A Review of the Marital Dyad. Social Casework, Vol. 36, pp. 259-265.

Bui \& Morash, 1999, p. 771.

Gelles \& Cornell (1990). Intimate Violence in Families. Newbury Park, CA: Sage Publications.

Bui \& Morash, 1999, p. 771. 
Gelles (1993). Alcohol and Other Drugs are Associated with Violence - They are not its Cause. In Gelles \& Loseke (Eds.), Current Controversies on Family Violence (pp. 182-196). Newbury Park, CA: Sage Publications.

Bui \& Morash, 1999, p. 771.

Bui \& Morash, 1999, p. 771.

Bui \& Morash, 1999, p. 772.

Dobash \& Dobash (1979). Violence Against Wives: A Case Against the Patriarchy. New York: Free Press.

Straus, Gelles \& Steinmetz (1980). Behind Closed Doors: Violence in the American Family. New York: Anchor.

Bui \& Morash, 1999, p. 771.

Bui \& Morash, 1999, p. 771.

Ceaser (1998). Exposure to Violence in the Families of Origin Among Wife Abusers and Maritally Non-Violent Men. Violence and Victims, Vol. 3, pp. 49-63.

Straus et al., 1980.

Bui \& Morash, 1999, p. 771.

Bui \& Morash, 1999, p. 772.

Dobash \& Dobash, 1979.

Bui \& Morash, 1999, p. 772.

Dobash \& Dobash, 1979.

Smith (1990). Patriarchal Ideology and Wife Beating: A Test of Feminist Hypothesis. Violence and Victims, Vol. 5, pp. 257-273.

Bui \& Morash, 1999, p. 772.

Haarr (2007). Wife Abuse in Tajikistan. Feminist Criminology, Vol. 2, No. 3, pp. 245-270.

Hegland (1992). Wife Abuse and the Political System: A Middle Eastern Case Study. In Counts, Brown \& Campbell (Eds.), Sanctions and Sanctuary: Cultural Perspectives on the 64 Dhuna në familje në Shqipëri: Vrojtim kombëtar me bazë popullatën Beating of Wives (pp. 203-227). Boulder, CO: Westview.

Abraham (2002). Speaking the Unspeakable: Wife Abuse among South Asian Immigrants in the United States. Rutgers, NJ: Rutgers University Press.

Bui \& Morash, 1999, p. 772.

Bui \& Morash, 1999, pp. 772-773.

Levinson (1989). Family Violence in Cross-Cultural Perspective. Newbury, CA: Sage Publications.

World Health Organization, WHO Multi-Country Study on Women's Health and Domestic Violence against Women (Geneva, Switzerland: 